Arboriculture \& Urban Forestry 2015. 41(6): 324-333

ISA

\title{
Why Opt-in to a Planting Program? Long-term Residents Value Street Tree Aesthetics
}

\author{
Dexter H. Locke, Lara A. Roman, and Colleen Murphy-Dunning
}

\begin{abstract}
Many cities are making substantial capital investments in urban tree planting. Residents play active and diverse roles in enhancing and protecting the urban forest, and are therefore critical to many municipal-level policy objectives. The way residents perceive and value the urban forest can have implications for achieving urban forestry goals through residents and volunteers. However, urban residents are not a monolithic block or homogenous category; instead, they have diverse opinions, needs, and constraints. Moreover, relatively little is known about how residents hear about available resources, such as free trees, and decide to 'opt-in' to tree planting initiatives, choosing to plant and maintain trees on or near their properties. The focus of this study was to address three questions about participation in a request-driven program that provides free street trees to residents of New Haven, Connecticut, U.S.: 1) Who requests trees through this program? 2) How did the requesters hear about this program? 3) Why did residents request free street trees?

Survey respondents were primarily long-term residents of New Haven; mostly learned about the opportunity from their neighbors; and requested a street tree to replace a removed tree, because they value the aesthetics, and to a lesser extent the environmental benefits. Future research should systematically investigate differences between participants and non-participants in local tree planting initiatives, exploring possible trends across cities and programs. Such studies would identify opportunities and barriers to engaging private residents in efforts aimed at increasing canopy.

Key Words. Connecticut; New Haven; Residential Ecosystems; Survey; Tree Planting; Tree Requests; Urban Tree Canopy.
\end{abstract}

Many cities in the United States (Young and McPherson 2013) and around the world are making substantial capital investments in urban tree planting. Urban forestry programs often engage individual residents as active urban forest stewards (Fisher et al. 2011; Romolini et al. 2012)-those who care and/or advocate for trees. Volunteers are often actively engaged in the planting, maintenance (e.g., water, prune), and monitoring of trees (Still and Gerhold 1997; Roman et al. 2013; Silva et al. 2013), whether through self-motivated community action or recruitment of local, urban greening organizations. Although professional arborists may be hired to do these same tasks, budgetary and staffing constraints often necessitate engaging other stakeholders in urban tree stewardship, including the public at large (Moskell et al. 2010). Additionally, engaging volunteers and residents can garner public support for urban forestry programs and create more informed constituencies
(Straka et al. 2005). Residents play active and diverse roles in enhancing and protecting the urban forest, and are therefore critical to many municipal-level policy objectives. Regarding the planting process specifically, residents act as stewards by identifying available street tree planting locations, requesting new street and yard trees, and carrying out the physical labor of planting (Rae et al. 2010; Turner and Mitchell 2013; Locke and Grove 2014). The purpose of this paper is to learn more about those who request trees through planting initiatives, and why such residents choose to optin, in order to inform improve outreach strategies.

The way residents perceive and value the urban forest can have implications for achieving urban forestry goals through residents and stewards. Homeowner tree support has been associated with general environmental concerns and pro-tree beliefs, and trees are particularly important when searching for a new place to live (Jones et al. 2012). 
Studies regarding public attitudes toward existing trees could inform outreach approaches for tree planting programs. Recent research in Seattle, Washington and Portland, Oregon, U.S., suggest residents in neighborhoods with relatively higher canopy-composed of longer-term residents with higher educational attainment-plant trees predominantly as part of other landscaping practices and as replacements for removed trees (Dilley and Wolf 2013; Donovan and Mills 2014. These varied studies point toward a common thread: the importance of tree aesthetics to urban residents.

However, there can be important local and regional variation in residential perceptions of urban trees (Schroeder and Ruffolo 1996; Schroeder et al. 2006). Urban residents are not homogenous; rather, they have diverse opinions, needs, and constraints. In Australian cities, Kirkpatrick and colleagues (2012) identified seven distinct clusters of general attitudes toward trees from a photographic elicitation study. Their results indicate that multiple sub-populations exist even among those who might respond favorably to new trees. This corroborates other research in Baltimore, Maryland (Grove et al. 2006; Troy et al. 2007; Boone et al. 2010), and New York City, New York, U.S. (Grove et al. 2014), where the amount of tree canopy and the opportunities for additional tree canopy in private residential land vary not just by socioeconomic status, but also by indicators of lifestyle and life stage, such as age and family size. These relationships between residents' perceptions and values, canopy cover, planting opportunities, and individual or household characteristics provide useful insights to engage the public in urban forestry initiatives, recognizing the diversity in preferences, opinions, and opportunities. This paper aims to address a gap in knowledge in the urban forest profession by attempting to understand why residents opt-in to a specific tree planting program.

As the preceding paragraphs indicate, prior research has addressed residents' attitudes towards urban forests. However, relatively little is known about how residents hear about available resources, such as free trees, and decide to opt-in to tree planting initiatives, choosing to plant and maintain trees on or near their properties. Because residents play many roles in caring for the urban forest, it is critical to understand who participates and why, because this will improve outreach and engagement strategies needed to cultivate enduring stewardship of urban natural resources. The focus of this study was to address three questions about participation in a request-driven program that provides free street trees to residents of New Haven, Connecticut, U.S.: 1) Who requests trees through this program? 2) How did the requesters hear about this program? 3) Why did residents request free street trees? The principle motivation was to elucidate the mechanisms behind requestbased tree planting programs in this case study city.

\section{METHOD}

\section{Study System}

With a population of 129,779 spread over approximately $50 \mathrm{~km}^{2}$, New Haven is the sixth most populous city in the New England area (U.S. Census Bureau 2011) and is situated approximately halfway between Boston, Massachusetts and New York City, New York, U.S. New Haven has a temperate climate. Like many cities in the northeastern United States, New Haven can be considered a post-industrial urban area.

Street trees in this study were distributed through a non-profit organization, the New Haven Urban Resources Initiative (URI). In 1991, URI was formed as a financially independent non-profit partnership with Yale University in New Haven, Connecticut, U.S. (URI 2015). URI is currently the official non-profit partner of the TreeHaven10k, New Haven's reforestation program. Acting as a contractor for the largely city-funded planting campaign, URI also uses the opportunity for a green job skills training program, and the trees are planted by high school students or adults with barriers to employment (Walsh 2013). Planting the trees solely based upon requests by residents, who must commit to follow-up watering, supports URI's mission of community-driven stewardship. Outreach strategies have expanded in recent years. The TreeHaven10k program includes street banners, advertisements in public transportation buses, canvassing door-to-door in low-canopy neighborhoods, tabling at public events, and emails from the city.

\section{Data Collection}

A survey was used to collect information about who requests trees through URI and why. URI maintains a list of email addresses for each street 
tree request. An email was sent to all of those who requested a street tree from 2007 through 2012, which included a link to the online survey. Recipients were made aware of the voluntary nature of their participation, the purpose of the survey, its length, and that the survey would be active for three weeks. Reminder emails were sent after two weeks and 36 hours before the survey closed. This method of participant recruitment was adapted from the Tailored Design Method (Dillman 1999). If a respondent indicated that he or she was less than 18 years old, the survey would automatically be terminated, but this never occurred.

The survey consisted of three main sections: 1) open-ended questions about URI and tree requests, 2) questions about specific values of trees, and 3) characteristics of the respondents. In the first section, two questions were asked: "How did you hear about URI?" and "Why did you request a tree from URI?" Openended questions have the advantage of not binding respondents or forcing their answers into preconceived categories, while allowing them to express their opinions in their own words (Fink 2009); this may therefore be considered a better representation of their underlying opinions. The open-ended questions were asked in the first section so that the subsequent questions about specific tree values would not prime or influence the responses.

The second section of the survey focused on the specific values of trees. Respondents were asked to evaluate thirteen phrases that complete the sentence, "I value urban trees because they ...", using a six-point rank-item scale that ranged from 1 (not at all important) to 6 (very important). The values were modified from a previous study (Westphal 1993), and contained a mix of phrases concerning aesthetics, ecosystem services, and social values. Space was provided for respondents to specify up to three additional values. Responses gathered from the write-in option were re-coded to fit within the original categories whenever possible, for situations in which the write-in answers were redundant with original categories.

The final section of the survey contained three questions about how long the respondent had lived in New Haven, whether the person owned their home, and where they considered themselves to be from. These questions were designed to help contextualize the population of respondents.

\section{Analyses}

The open-ended questions were first manually organized into categories, using qualitative coding (Babbie 2007; Saldaña 2012), and then a single coder tabulated their frequencies. Responses that described multiple and distinct reasons were placed into multiple categories. For example, a respondent indicated they requested a street tree because, "There were no trees in front of my home and it looked barren," which was categorized into the categories "lacked trees" and "aesthetics." Fixed-response questions were tabulated to examine frequencies.

A goal of this study was to understand perceptions of street trees among resident-initiated requests for street trees. Perceptions cannot be directly measured and may therefore be considered a latent variable. The survey collected data on the values of trees, which can be measured, and can reasonably be linked to one's underlying perceptions. To identify latent variables for perceptions, the study authors employed Exploratory Factor Analysis (EFA), a statistical technique designed to aid the researcher in identifying a set of latent constructs or "factors" that account for correlations among observed and measured variables (Fabrigar et al. 1999). As such, EFA is data-driven approach to reveal latent constructs from their proxy measures. In this instance, perceptions are the factors of interest, and values of trees are the measured variables.

\section{RESULTS}

The survey was emailed to all 460 people who requested street tree from 2007 through 2012, and 171 responded, for an overall response rate of $37 \%$. Respondents were primarily long-term residents of New Haven (Figure 1). Nineteen percent of respondents indicated they had lived in the city for 10 to 20 years, while $52 \%$ lived in New Haven for more than 20 years. Nearly the whole sample of tree requesters owned their own home (90\%). Forty-eight percent of respondents were from Connecticut, $45 \%$ from another state, and 
$7 \%$ indicated they were from outside the United States. Only $1 \%$ of respondents (two people) opted for the Spanish-language version of the survey. When asked about how they heard about URI, nearly $50 \%$ of respondents indicated that they heard from a neighbor. Other communication channels about the program were substantially less common: $14 \%$ of respondents learned about the program from URI itself and anoth- er $12 \%$ from newspapers and/or newsletters. According to the coded open-ended responses, the most common reasons to request a tree are to replace a removed tree $(30 \%)$, aesthetics $(30 \%)$, and environmental services (17\%; Figure 1).

Partially consistent with the answers to the open-ended questions, aesthetics and ecosystem services were the most highly-rated values of trees from the preset categories with scale items

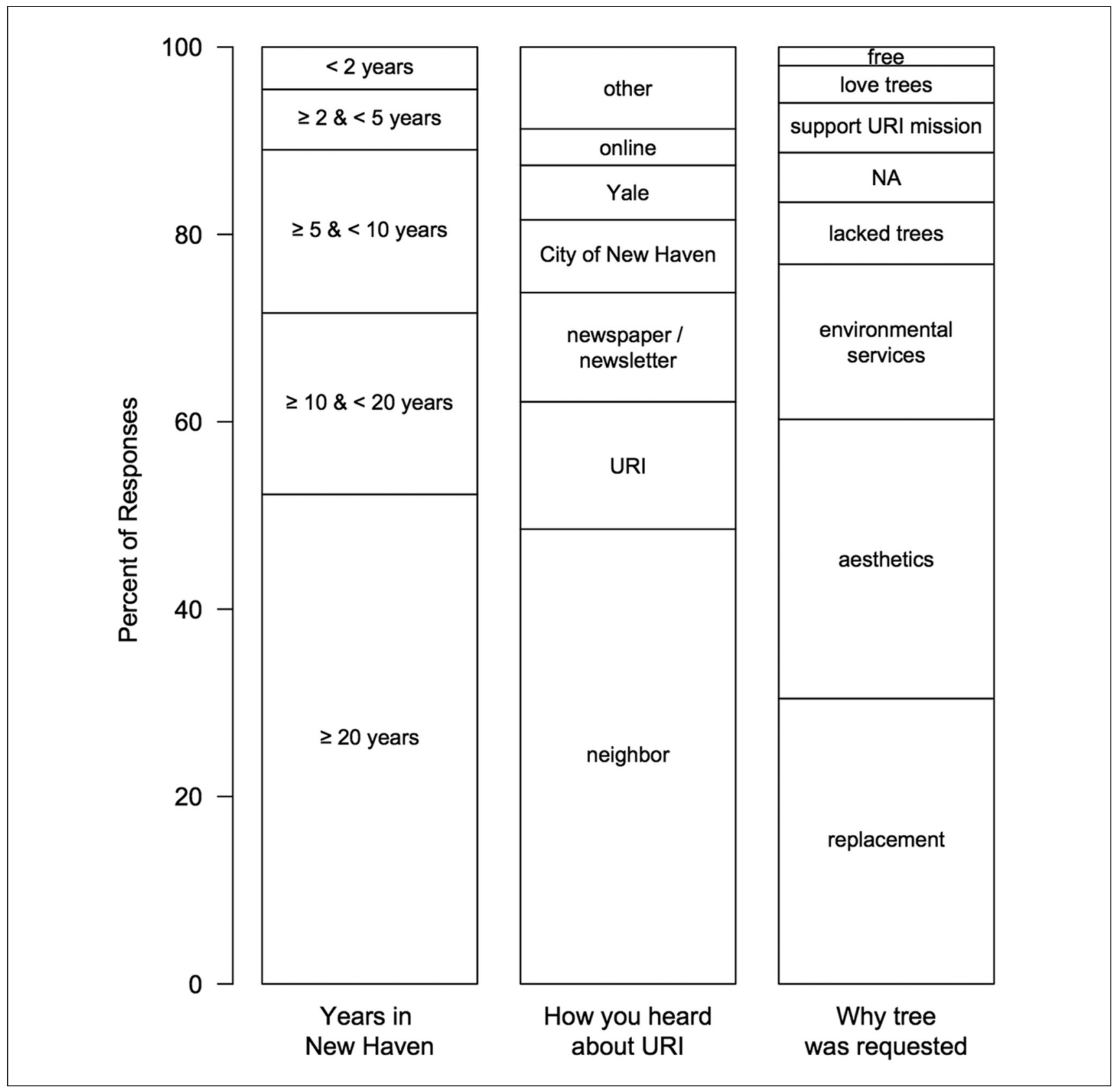

Figure 1. Percent of responses for the questions "How many years have you lived in New Haven," "How did you hear about URI," and "Why was the tree requested." The "other" block in "How you heard" is a combination of do not recall, alderman, green expo, and farmers market. 
responses (Figure 2). However, communitarian values, such as increases sense of community and "my family will enjoy the tree in the future," were also popular answer choices. The mean and median values for these questions were always positive (i.e., above the neutral value of 3.5 on the 6 -item scale), except for "slows wind" (mean $=3.1$, median $=3$ ), so all categories received relatively favorable scores overall. "Slows wind" aside, the medians were always greater than the mean indicating that the distributions are skewed to the left. However, as Figure 2 also shows, the respondents expressed somewhat diverging feelings towards property value, screen views, noise reduction, and slowing of wind, and there are apparent bimodal distributions for those values. Thirty-five participants offered write-in responses to the question about why they value trees. Overall, 21 respondents collectively provided 29 write-in answers that corresponded to one of the existing options. In every case, these survey participants had actually already checked the relevant preset category, and their write-in response merely provided additional nuance. For example, 15 respondents had writein comments that were deemed to belong to the original preset category "good for the environment," such as "nature friendly," "retains water," "produce oxygen," and "absorbs pollutants." Answers to the write-in option that did not correspond to any of the preset categories are indicative of topics not covered by the initial list of categories. Overall, 28 values were provided by 23 unique respondents that did not resemble the initial categories. The most common write-in responses of that type related to intrinsic values of trees with responses such as "I love trees" and "More trees are just good."

Using EFA to highlight dominant themes across and among the answer choices, three factors explain $50 \%$ of the cumulative variation. Three factors were retained, based on the scree plot, the need to keep an appropriate ratio of variables to factors, an examination of the cumulative variance explained, and eigen values $>1$; these methods are commonly used to determine the most appropriate number of factors to retain in EFA (Fabrigar et al. 1999). Average communality was 0.5 , with

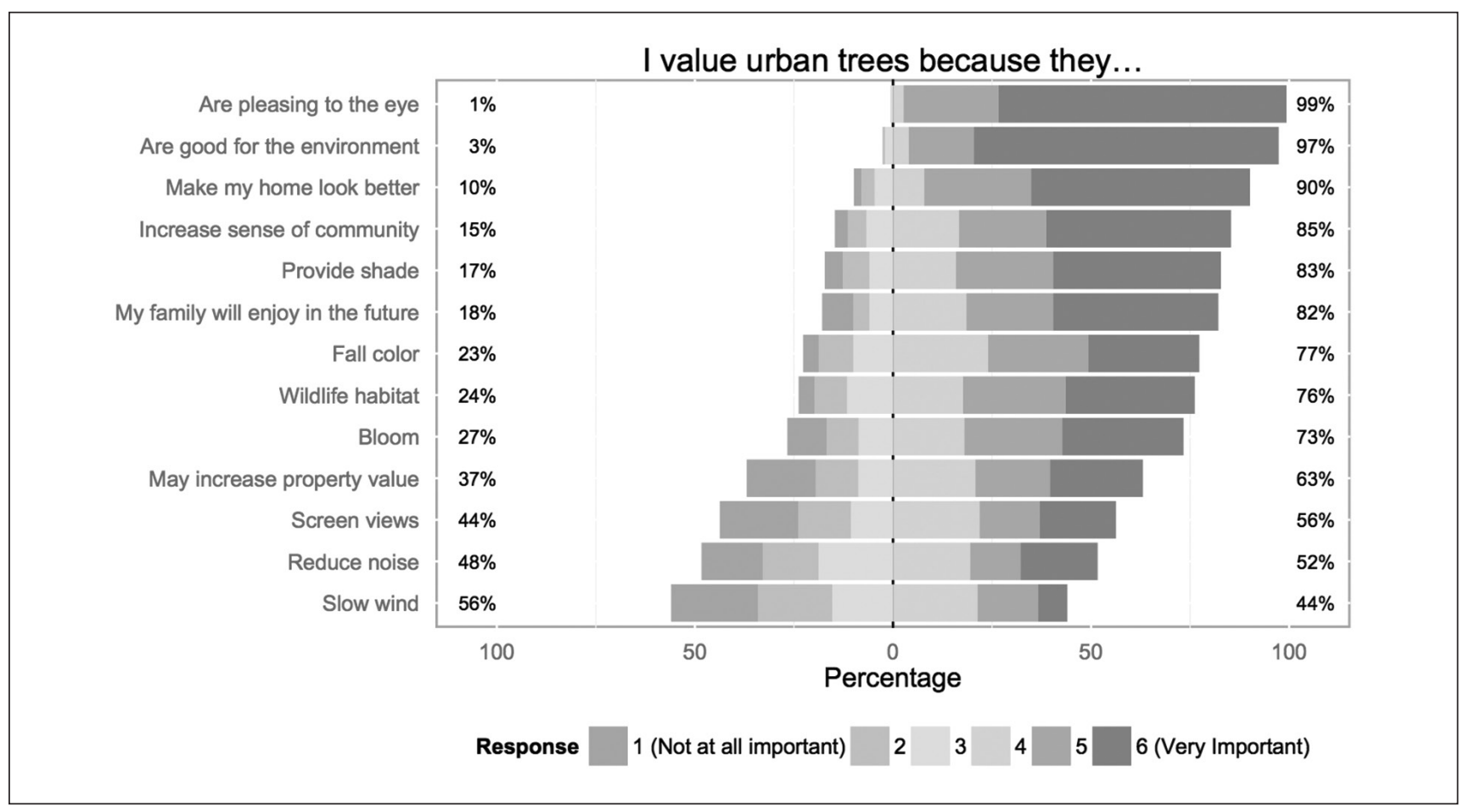

Figure 2. Values attributed to urban trees by tree requesters. Respondents rated each value on a 1 (not at all important) to 6 (very important) rank-item scale. Percentages on the left refer to the sum of scores in the 1-3 range, and the percentages on the right correspond to sum of scores in the 4-6 range. For example, $90 \%$ of respondents indicated that they value trees because they "make my home look better" (with rank scale scores of 4 or above). 
Table 1. Factor loadings for the three factors retained from EFA analysis. Higher loadings indicate greater relevance in determining the factors' dimensions. Only loadings greater than 0.35 are displayed.

\begin{tabular}{lll}
\hline & $\begin{array}{l}\text { Factor1: Environment, } \\
\text { community \& aesthetics }\end{array}$ & $\begin{array}{l}\text { Factor2: Comfort } \\
\text { \& shelter }\end{array}$ \\
\hline Make my home look better & 0.55 & \\
Increase sense of community & 0.64 & \\
Are good for environment & 0.74 & \\
Pleasing to the eye & 0.59 & 0.55 \\
Screen views & & 0.82 \\
Slow wind & & 0.81 \\
Reduce noise & & \\
May increase property values & & 0.44 \\
Provide shade & 0.48 & 0.39 \\
Wildlife habitat & 0.37 & 0.48 \\
My family will enjoy in the future & 0.47 & \\
Fall color & 0.38 & 1.481 \\
Bloom & 5.191 & $19 \%$ \\
Eigenvalues & $20 \%$ & $39 \%$ \\
Variance explained & $20 \%$ & 0.94 \\
Cumulative variance explained & & \\
\hline
\end{tabular}

"may increase property values" extremely reliable (communality $=1$ ), while "Bloom" and "My family will enjoy in the future" the least reliable (communalities $=0.25$ and 0.29 , respectively). Based the factor loadings, the authors applied factor labels as follows: "Environment, community \& aesthetics," "Comfort \& shelter," and "Home \& property" (Table 1). EFA was applied only to the responses from the pre-set categories.

\section{DISCUSSION}

Respondents were primarily long-term residents of New Haven, who heard about URI through their neighbors, and requested trees as a replacement for a removal, or for the trees' aesthetic qualities (Figure 1). The single highest-rated reason for valuing urban trees (Figure 2) was, "are pleasing to the eye" ( $99 \%$ favorable rating, i.e., rated with 4 or higher on 6-point scale item). This was closely followed by "good for the environment" ( $97 \%$ favorable rating). The third and fourth highest-rated values for urban trees were, "make my home look better" (90\% favorable rating) and "increase sense of community" (85\% favorable rating), respectively. The EFA findings also suggest that feelings about aesthetics and a sense of community are coupled with the abstract concept of "environment," whereas more tangible and direct benefits (e.g., slowing wind, reducing noise) formed another distinct dimension of values. When taken together, these results suggests that emphasis on aesthetics and community in planting program communication and outreach may gain more traction than emphasis on specific ecosystem services (Silvera Seamans 2013), at least among the long-time residents sampled. Only one coder analyzed the open-ended qualitative data, so no formal inter-rater reliability analyses were possible, which is a possible source of bias. However, the triangulation of the fixed response frequencies, as well as the EFA, consistently revealed similar values and motivations for requesting trees as the qualitative data suggested.

Because tree replacement was a primary motivation among the open-ended responses, this may suggest that well-canopied communities are perhaps more likely to remain well-treed areas, at least with respect to the street tree population. Such patterns have been observed in Portland, Oregon; Washington, D.C.; and Baltimore, Maryland, U.S., where participation in free or reducedcost plantings were most popular in areas with higher socioeconomic status or more existing canopy (Donovan and Mills 2014; Locke and Grove 2014). Additionally, because the majority of respondents heard about the program from their neighbors, and "sense of community" was a highly-rated tree value, neighborhood norms and values regarding vegetation and landscaping (Larsen and Harlen 2006; Larson et al. 2009) likely play important roles for request-based tree planting programs. However, the results could not tease apart how the initial neighbors had heard about the program. There are potential dynamics at play connecting neighborhood greenness, social connectivity, and street tree planting that 
should be explored in future research, building on past studies that show how the natural environment can increase social contacts (Coley et al. 1997; Kweon et al. 1998; Kim and Kaplan 2004).

Other recent research in New Haven, which took place during the same time period, complements the survey results presented here to describe and contextualize the relationships between socioeconomic characteristics and tree requesters (Locke and Baine 2014). Addresses representing street tree requests from the autumn 2007 through autumn 2011 were analyzed for socioeconomic patterns. There was a positive correlation between rentership levels (at the U.S. Census block group scale) and tree request density. No correlation was found between the density of street tree requests and median household income or race. This shows that the URI free street tree program serves renting communities and communities across the entire range of household incomes found within the City of New Haven. Some stewardship groups may conserve existing tree canopy, while others work to establish or create it (Romolini et al. 2013), and different supporting strategies might be needed in these different cases.

The survey respondents-mostly homeowners-were thus not representative of all street tree requesters, rather, they are a select subset, defined in part by high rates of home ownership. The survey results presented here suggest that for this sub-population, motivations for tree requests are driven by a desire for beauty and to replace removed trees. Respondents also reported valuing the abstract concept of the environment, community and aesthetics, as distinct from more tangible ecosystem services, and the belief that trees will improve property values. In-depth interviews would be necessary to elucidate why residents conceptually grouped environment, community, and aesthetics. The survey likely missed renters as well as participants without internet access. It is possible that other benefits of trees, and other means of communicating those benefits, would be effective with other subpopulations and/or demographic groups. For example, among survey respondents, the availability of free street trees was predominantly communicated through neighbors, which underscores the importance of neighborhood- or community-based outreach strategies that increase social contacts. Future research regarding tree requesters in this and other urban forestry programs could employ indepth interviews and/or surveys sent more immediately after tree planting. The write-in responses that did not correspond to the preset categories could be added to future assessments. In this study, three respondents indicated they requested the tree because they are not physically able to plant a tree on their own. Three others said they value trees for the traffic calming effects. These findings present an opportunity to strengthen future research designed to understand who elects to participate in free-tree programs and why they opt-in to such programs, which can facilitate outreach and engagement for specific subpopulations.

Although the New Haven results presented here are representative of one case, the questions, methods, and approach implemented here are readily extensible to other programs. Such baseline studies could permit cross-site comparisons with diverse programs in other cities to better understand participation in free-tree programs more broadly and to evaluate outreach strategy effectiveness in light of resident perceptions and values. This avenue of research could lead to more successful tree planting initiatives that meet the needs of different residents. This could be accomplished through a better matching of programmatic planting objectives, outreach strategies, and residents' motivations, capacities, and interests informed through ongoing evaluations.

\section{CONCLUSION}

The goals of this study were to understand how residents learned about urban forestry programs (and free trees made available by URI in particular), describe who requests free street trees through this program, and assess why they requested a tree. Addressing these questions is necessary due to the explosion of interest in urban forestry programs among policy makers and funders, as well as the central role of residents and volunteers in urban forest stewardship. Survey respondents mostly learned about the opportunity from their neighbors; were primarily long-term residents of New Haven; and requested a street tree to replace a removed tree, because they value the aesthetics, and to a lesser extent, the environmental benefits. Future re- 
search should systematically investigate differences between participants and non-participants in local tree planting initiatives, and explore possible trends across cities and programs. Such studies would identify opportunities and barriers to engaging private residents in efforts aimed at increasing canopy.

Acknowledgments. The authors thank Anna Ruth-Pickett and the Urban Resources Initiative, as well as Geoff Feinberg of the Yale Project on Climate Change Communication and Amity Doolittle for their assistance and insights into the design of this project. William Collier provided useful input on the factor analyses. The authors also thank Sarah Low, Geoffrey Donovan and John Stanovick, and David Nowak for helpful comments on previous versions. The anonymous reviewers provided constructive and helpful feedback, thank you. This research was deemed exempt by the Yale Human Subjects Committee under 45 CFR 46.101(b)(2). The Edna Bailey Sussman Foundation, the Libby Fund Enhancement Award, the Marion I. Wright ' 46 Travel Grant, the Graduate School of Geography at Clark University provided support for this research. The authors extend their greatest thanks to those who requested street trees, and took the time to tell us why. Without these urban forest stewards New Haven would be less green and this study would not have been possible.

\section{LITERATURE CITED}

Babbie, E.R. 2007. The basics of social research. Wadsworth Publishing. $576 \mathrm{pp}$.

Boone, C.G., M.L., Cadenasso, J.M. Grove, K. Schwarz, and G.L. Buckley. 2010. Landscape, vegetation characteristics, and group identity in an urban and suburban watershed: Why the 60 s matter. Urban Ecosystems 13(3): 255-271. doi:10.1007/s11252009-0118-7

Coley, R. L., W.C. Sullivan, and F.E. Kuo. 1997. Where does community grow? The social context created by nature in urban public housing. Environment and Behavior 29(4):468-494. doi:10.1177/001391659702900402.

Dilley, J., and K.L. Wolf. 2013. Homeowner interactions with residential trees in urban areas. Arboriculture \& Urban Forestry. 39(6):267-277.

Dillman, D.A. 1999. Mail and Internet Surveys: The Tailored Design Method, second edition. Wiley \& Sons, New York, New York, U.S. 480 pp.

Donovan, G., and J. Mills. 2014. Environmental justice and factors that influence participation in tree planting programs in Portland, Oregon, U.S. Arboriculture \& Urban Forestry 40(2):70-77.

Fabrigar, L.R., D.T. Wegener, R.C. MacCallum, and E.J. Strahan. 1999. Evaluating the use of exploratory factor analysis in psychological research. Psychological Methods 4(3):272-299. doi:10.1037//1082-989X.4.3.272.

Fink, A. 2009. How to Conduct Surveys: A Step-by-Step Guide. SAGE. $125 \mathrm{pp}$.

Fisher, D.R., J.J. Connolly, E.S. Svendsen, and L.K. Campbell. 2011. Digging Together: Why people volunteer to help plant one million trees in New York City. Accessed 01 October 2014. <http:// nrs.fs.fed.us/nyc/local-resources/downloads/Digging_Together_White_Paper.pdf>
Grove, J.M., A.R. Troy, J.P.M. O’Neil-Dunne, W.R.J. Burch, M.L. Cadenasso, S.T.A. Pickett, and M. Wilson, M. 2006. Characterization of households and its implications for the vegetation of urban ecosystems. Ecosystems 9(4):578-597. doi:10.1007/ s10021-006-0116-z.

Grove, J.M., D.H. Locke, and J.P.M. O’Neil-Dunne. 2014. An Ecology of prestige in New York City: Examining the relationships among population density, socio-economic status, group identity, and residential canopy cover. Environmental Management 54(3):402-419. doi:10.1007/s00267-014-0310-2.

Jones, R.E., K.L. Davis, and J. Bradford. 2012. The value of trees: Factors influencing homeowner support for protecting local urban trees. Environment and Behavior 45(5):650-676.

Kim, J., and R. Kaplan. 2004. Physical and psychological factors in sense of community: New urbanist Kentlands and nearby Orchard Village. Environment \& Behavior 36(3):313-340. doi: $10.1177 / 0013916503260236$.

Kirkpatrick, J.B., A. Davison, and G.D. Daniels. 2012. Resident attitudes towards trees influence the planting and removal of different types of trees in eastern Australian cities. Landscape and Urban Planning 107(2):147-158. doi:10.1016/j.landurbplan.2012.05.015.

Kweon, B.-S., W.C. Sullivan, and R.A. Wiley. 1998. Green common spaces and the social integration of inner-city older adults. Environment and Behavior 30(6):832-858. doi:10.1177/001391659803000605.

Larsen, L., and S.L. Harlan. 2006. Desert dreamscapes: Residential landscape preference and behavior. Landscape and Urban Planning 78(1-2):85-100. doi:10.1016/j.landurbplan.2005.06.002.

Larson, K., D.G. Casagrande, S.L. Harlan, and S. Yabiku. 2009. Residents' yard choices and rationales in a desert city: Social priorities, ecological impacts, and decision tradeoffs. Environmental Management 44:921-937. doi:10.1007/s00267-009-9353-1.

Locke, D.H., and G.T. Baine. 2014. The good, the bad, and the interested: How historical demographics explain present-day tree canopy, vacant lot and tree request spatial variability in New Haven, CT. Urban Ecosystems. <http://dx.doi.org/10.1007/ s11252-014-0409-5>

Locke, D.H., and J.M. Grove. 2014. Doing the Hard Work Where It's Easiest? Examining the relationships between urban greening programs and social and ecological characteristics of Baltimore, MD and the District of Columbia. Submitted to Applied Spatial Analysis and Policy on 08 September 2014.

Moskell, C., S.B. Allred, and G. Ferenz. 2010. Examining motivations and recruitment strategies for urban forestry volunteers. Cities and the Environment (CATE) 3(1):1-28.

Rae, R.A., G. Simon, and J. Braden. 2010. Public reactions to new street tree planting. Cities and the Environment (CATE) 3(1):1-21.

Roman, L., G.E. McPherson, B. Scharenbroch, and J. Bartens. 2013. Identifying common practices and challenges for local urban tree monitoring programs across the United States. Arboriculture \& Urban Forestry 39(6):292-299.

Romolini, M., J.M. Grove, and D.H. Locke. 2013. Assessing and comparing relationships between urban environmental stewardship networks and land cover in Baltimore and Seattle. Landscape and Urban Planning 120:190-207. doi:10.1016/j.landurbplan.2013.08.008. 
Romolini, M., W. Brinkley, and K.L. Wolf. 2012. What Is Urban Environmental Stewardship? Constructing a PractitionerDerived Framework. Research Note PNW-RN-566, Pacific Northwest Research Station, U.S. Department of Agriculture, Forest Service. 41 pp. Accessed 01 October 2014. <www.naturewithin.info/CivicEco/pnw_rn566_USFS_3CM_Rsrch_ Note.pdf>

Saldaña, J. 2012. The Coding Manual for Qualitative Researchers (No. 14). SAGE.

Schroeder, H., J. Flannigan, and R. Coles. 2006. Residents' attitudes toward street trees in the UK and U.S. communities. Arboriculture \& Urban Forestry 32(5):236-246.

Schroeder, H.W., and S.R. Ruffolo. 1996. Householder Evaluations of Street Trees in a Chicago Suburb. Journal of Arboriculture 22(1):35-43.

Silva, P., E. Barry, and S. Plitt. 2013. TreeKIT: Measuring, mapping, and collaboratively managing urban forests. Cities and the Environment (CATE). 6(1):1-19.

Silvera Seamans, G. 2013. Mainstreaming the environmental benefits of street trees. Urban Forestry \& Urban Greening 12(1):2-11.

Still, D.T., and H.D. Gerhold. 1997. Motivations and task preferences of urban forestry volunteers. Journal of Arboriculture 23:116-129.

Straka, T.J., A.P. Marskino, and C.J. Childers. 2005. Individual characteristics affecting participation in urban and community forestry programs in South Carolina, U.S. Arboriculture \& Urban Forestry 31:31-137.

Troy, A.R., J.M. Grove, J.P.M. O’Neil-Dunne, S.T.A. Pickett, and M.L. Cadenasso. 2007. Predicting opportunities for greening and patterns of vegetation on private urban lands. Environmental Management 40(3):394-412. doi:10.1007/s00267-006-0112-2.

Turner, C., and M. Mitchell. 2013. Planting the Spaces in Between: New York Restoration Project's Tree Giveaway Program. Cities and the Environment (CATE). 6(1).

URI. 2015. Urban Resource Initiative-Yale School of Forestry \& Environmental Studies. <http://environment.yale.edu/uri>

U.S. Census Bureau. 2011. "Table 1. Annual Estimates of the Resident Population for Incorporated Places Over 50,000, Ranked by July 1, 2011 Population: April 1, 2010 to July, 2011” (CSV). 2011 Population Estimates. United States Census Bureau, Population Division. Accessed 04 August 2012.

Walsh, D. 2013. Green Jobs for Ex-Offenders: The Urban Resource Initiative's "GreenSkills" Program. Cities and the Environment (CATE), 6(1).

Westphal L.M. 1993. Why trees? Urban forestry volunteers values and motivations. In: P. Gobster (Ed.). Managing urban and high-use recreation settings. USDA Forest Service North Central Research Station, St. Paul.

Young, R.F., and E.G., McPherson. 2013. Governing metropolitan green infrastructure in the United States. Landscape and Urban Planning 109(1):67-75. doi:10.1016/j.landurbplan.2012.09.004.
Dexter H. Locke (corresponding author)

Graduate School of Geography

Clark University

950 Main Street

Worcester, Massachusetts 01610-1477, U.S.

email:dexter.locke@gmail.com

phone: 3104636202

Lara A. Roman

USDA Forest Service

Northern Research Station

Philadelphia Field Station

100 N. 20th St., Suite 205

Philadelphia, Pennsylvania 19103, U.S.

lroman@fs.fed.us

Colleen Murphy-Dunning

Director, Hixon Center for Urban Ecology

Director Urban Resources Initiative Yale School of Forestry \& Environmental Studies

195 Prospect Street

New Haven, Connecticut 06511, U.S.

colleen.murphy-dunning@yale.edu 
Résumé. Plusieurs municipalités investissent des sommes importantes dans la plantation d'arbres en milieu urbain. Les résidents jouent des rôles aussi actifs que diversifiés dans la mise en valeur et la préservation de la forêt urbaine et par conséquent, se montrent critiques quant aux objectifs des politiques municipales. La manière dont les résidents perçoivent et apprécient la forêt urbaine peut avoir des incidences sur l'atteinte des objectifs de la foresterie urbaine par l'entremise justement des résidents et des bénévoles. Toutefois, les résidents urbains ne constituent pas un bloc monolithique ou une catégorie homogène, ils ont des opinions, des besoins et des contraintes diversifiées. En outre, on sait relativement peu de choses sur la manière dont les citoyens apprennent l'existence de ressources disponibles tel le don d'arbres et décident de participer à des initiatives pour la plantation d'arbres, choisissant de planter et d'entretenir des arbres sur leur terrain ou à proximité. L'objectif de cette étude était de répondre à trois questions concernant la participation à un programme visant la fourniture d'arbres d'alignement offerts gratuitement aux résidents de New Haven, Connecticut, États-Unis: 1) Quels sont les individus souhaitant obtenir des arbres via ce programme? 2) Comment les requérants entendent-ils parler de ce programme? 3) Pourquoi les résidents souhaitent-ils obtenir des arbres d'alignement gratuits?

Zusammenfassung. Viele Städte investieren große Summen in die Pflanzung von Stadtbäumen. Anwohner spielen aktive und diverse Rollen bei der Verbesserung und Schutz von urbanen Baumbeständen und sind daher sehr kritisch gegenüber einigen Zielsetzungen der Verwaltungen. Die Weise, in welcher die Anwohner ihre Bäume wahrnehmen und schätzen, kann Auswirkungen auf die Ereichung von Zielen im Baummanagement durch Anwohner und Freiwillige haben. Dennoch sind die Stadtbewohner kein monolithischer Block oder eine homogene Kategorie, stattdessen haben sie unterschiedliche Meinungen, Bedürfnisse und Ein- schränkungen. Darüber hinaus ist wenig bekannt, wie die Anwohner ihre Informationen über verfügbare Ressourcen erhalten, wie kostenlose Bäume und wie sie einsteigen in Baumpflanzaktionen, Auswahl der Pflanzen und Pflege der Bäume auf oder in der Nähe ihres Eigentums. Der Fokus dieser Studie war, den Anwohnern drei Fragen über die Teilnahme an einem Nachfragegesteuertem Programm zu stellen, welches kostenlose Straßenbäume an Anwohner in New Haven, Connecticut, U.S. liefert: 1) Wer ruft durch dieses Programm Bäume ab?, 2) Wie erfahren diese Personen über das Programm?, und 3) Warum fragen die Anwohner nach kostenlosen Straßenbäumen?

Resumen. Muchas ciudades están haciendo inversiones sustanciales de capital en la plantación de árboles urbanos. Los residentes desempeñan un papel activo y roles diversos en la mejora y protección del bosque urbano, por lo que son fundamentales para muchos objetivos de política a nivel municipal. La manera en que los residentes perciben y valoran el bosque urbano puede tener implicaciones para el logro de las metas de la dasonomía urbana a través de los residentes y voluntarios. Sin embargo, los residentes urbanos no son un bloque monolítico o categoría homogénea; en cambio, tienen diversas opiniones, necesidades y limitaciones. Por otra parte, se sabe relativamente poco sobre cómo se informan acerca de los recursos disponibles, tales como árboles gratuitos y deciden incluirse en las iniciativas de plantación de árboles, elección de plantas y mantener árboles en o cerca de sus propiedades. El objetivo de este estudio fue abordar tres preguntas sobre la participación en un programa de petición dirigida que ofrece árboles gratuitos a los residentes de New Haven, Connecticut, Estados Unidos: 1) ¿Quién solicita árboles a través de este programa? 2) ¿Cómo los solicitantes se enteran del programa? 3) ¿Por qué los residentes solicitan árboles gratuitos? 